\title{
The impact of economic and financial factors on UK property performance
}

Article

Accepted Version

Brooks, C. and Tsolacos, S. (1999) The impact of economic and financial factors on UK property performance. Journal of Property Research, 16 (2). pp. 139-152. ISSN 1466-4453 doi: https://doi.org/10.1080/095999199368193 Available at https://centaur.reading.ac.uk/35976/

It is advisable to refer to the publisher's version if you intend to cite from the work. See Guidance on citing.

Published version at: http://dx.doi.org/10.1080/095999199368193

To link to this article DOI: http://dx.doi.org/10.1080/095999199368193

Publisher: Routledge

All outputs in CentAUR are protected by Intellectual Property Rights law, including copyright law. Copyright and IPR is retained by the creators or other copyright holders. Terms and conditions for use of this material are defined in the End User Agreement.

\section{www.reading.ac.uk/centaur}

\section{CentAUR}

Central Archive at the University of Reading

Reading's research outputs online 
This is an Author's Accepted Manuscript of an article published in the Journal of Property Research (1999) [copyright Taylor \& Francis], available online at: http://www.tandfonline.com/10.1080/095999199368193 


\title{
The Impact of Economic and Financial Factors on UK Property Performance
}

\author{
Chris Brooks ${ }^{1}$, ISMA Centre, Department of Economics, University of Reading \\ and
}

Sotiris Tsolacos, Centre for Spatial and Real Estate Economics, Department of Economics, University of Reading

5 October 1998

\begin{abstract}
This paper employs a vector autoregressive model to investigate the impact of macroeconomic and financial variables on a UK real estate return series. Our results indicate that unexpected inflation, and the interest rate term spread have explanatory power for the property market. However the most significant influence on the real estate series are the lagged values of the real estate series themselves. We conclude that identifying the factors that have determined UK property returns over the past twelve years remains a difficult task.
\end{abstract}

J.E.L. Classifications: C32, C52

Keywords: property returns, macroeconomy, vector autoregressions

${ }^{1}$ Brooks (Corresponding author), ISMA Centre, PO Box 242, The University of Reading, Whiteknights, Reading RG6 6BA; e-mail: C.Brooks@ @eading.ac.uk. The authors are grateful to four anonymous referees for useful comments on an earlier version of this paper. The usual disclaimer applies. 


\section{Introduction}

Much research in the real estate returns literature has placed emphasis on the macroeconomic factors which influence real estate returns. As such, this body of literature attempts to identify exogenous forces which determine real estate returns through time. This is an area in the real estate field that requires further investigation, as Ling and Naranjo (1997) have recently pointed out. Empirical work on the links between the macroeconomy and real estate returns has been mainly carried out using U.S. data. Chan et al (1990), for example, examine the effect of a number of prespecified macroeconomic variables within a multifactor arbitrage pricing model. Their results, obtained from regression analysis, demonstrated the importance of changes in the risk and term structure in explaining real estate return movements. Other macroeconomic series such as changes in industrial production, changes in expected and unexpected inflation did not receive empirical support. Liu and Mei (1992) model excess returns on real estate investment trusts (REITs) using variables that have been used by relevant studies on stock market returns. The starting point in their analysis is that the variation in expected excess returns arises from changes in business conditions. The authors conclude that the capitalisation rate (a property market variable), the dividend yield and the Treasury Bill explain components of excess returns. They also included a term spread variable, but this was found not to be important.

McCue and Kling (1994) examined the responses of real estate returns to shocks originating in a number of prespecified macroeconomic variables. These authors initially transformed the return series to exclude the stock market effect on equity REIT data. The macroeconomic variables included in the model were based on the physical capital investment model of Lawrence and Siow (1985). It was found that these macroeconomic variables explained about sixty per cent of the variation in the equity REITs series. Nominal interest rates appeared to 
have the most significant influence. Industrial output and a measure of investment (the McGraw Hill Construction Contract Index) explained very little of the return structure.

More recently, Ling and Naranjo (1997) estimated the influence of macroeconomic factors on the behaviour of real estate asset returns and to investigate whether factors which have persistent influence on asset returns are priced ex ante. Their selection of macroeconomic variables was based on previous studies of stock market returns (Chen et al, 1986; Ferson and Harvey, 1991). This study concluded that the growth rate in real per capita consumption, the real Treasury bill rate, the term structure of interest rates and unexpected inflation have systematic influences on commercial real estate returns.

In Great Britain and in continental Europe, the relationship between the macroeconomy and real estate returns has attracted less research interest. The Royal Institution of Chartered Surveyors (1994) argued that the peaks and troughs of the property return cycle have happened in the same year as the turning points in the longer leading indicator constructed by the Office for National Statistics. These cyclical comovements were less apparent when the longer leading indicator was replaced by the gross domestic product growth rate. Lizieri and Satchell (1997a) examined the relationship between property returns and the overall equity market. They illustrated that alternative theoretical frameworks imply different relationships between stock market and property market returns. In their analysis, they assumed strong real estate influences on ordinary shares, and extracted the influence of the property market from the overall equity market. Therefore, unlike McCue and Kling (1994) property returns are not treated as a residual. Granger causality tests were subsequently carried out by Lizieri and Satchell to examine the relationship between the behaviour of Financial Times property returns and equity returns after the property effect was removed. They discovered a strong 
relationship between property returns and lagged values of equity returns adjusted for property influences. On the other hand, the inverse relationship appeared to hold only in the long run. Lizieri and Satchell also acknowledge the possibility that a third (unspecified) factor may influence returns both on the overall stock market and on property backed assets.

In other research, Lizieri and Satchell (1997b) used threshold autoregressive models to examine the relationship between real interest rates and property prices. The authors argue that there are strong a priori grounds for modelling interest rate impacts on property prices. They concluded that the rate of real interest, or more precisely the ratio of the nominal interest rate to the inflation rate, has an influence on property company share prices. The study also found that this impact is non-linear. During periods of relatively high interest rates, property share prices fall sharply and exhibit little volatility. However, during periods of relatively low interest rates, price movements are more erratic.

The objective of this study is to further research on the linkages between the macroeconomy and property returns and to provide evidence on the effect of predetermined macroeconomic variables on property returns in the UK. Since the bulk of relevant research has been undertaken in the US, similar studies in other macroeconomic and property market environments are expected to generate useful comparative evidence. A vector autoregressive (VAR) methodology is employed for the empirical investigation and monthly data are used for the period December 1985 to January 1998. Since most of the US studies examine the variation in property returns using monthly data, it is considered appropriate to conduct an investigation in the present paper with data of similar frequency. This will facilitate comparisons of our findings in the UK context with the results available in the extant literature. 
The selection of the variables for inclusion in the VAR model in this paper is governed by the time series which are commonly included in studies of stock return predictability. It is assumed that stock returns are related to macroeconomic and business conditions, and hence time series which capture a priori both current and future directions in the broad economy and the business environment are used in these investigations. In this study, movements in real estate returns are also related to changing trends in the economic and business climate as reflected in the variation of the following variables: the rate of unemployment, nominal interest rates, the spread between the long and short term interest rates, unanticipated inflation and the dividend yield. The rate of unemployment is included to indicate general economic conditions. The selection of this proxy variable is partly the pragmatic result of the use of monthly data in this study that restricts the choice of alternative variables which describe the real economy because data are not available at this frequency. In existing research, authors tend to use aggregate consumption, a variable which has been built in asset pricing models and examined as a determinant of stock returns (Lucas, 1978; Breeden, 1979; Chen et al, 1986; Breeden et al, 1989; Ferson and Harvey, 1991). Ling and Naranjo (1997) used this variable (real per capita consumption growth) to explain excess returns on real estate assets and provided supportive evidence. Data for this variable and for alternative variables such as GDP are not available on a monthly basis in the UK. Monthly data are available for the industrial production series but the work of Ling and Naranjo (1997), McCue and Kling (1994) and Chan et al (1990) did not show any evidence that industrial production affects real estate returns. As a result this series was not considered as a potential causal variable.

The nominal interest rate is a macroeconomic series which is assumed to contain information about future economic conditions and to capture the state of investment opportunities. It has 
therefore been included in the studies of stock market returns either in nominal or real terms (Campbell, 1987; Fama and French, 1989; Chen, 1991; Ferson and Harvey, 1991). McCue and Kling (1994) claimed that interest rates have a very significant negative influence on equity REIT returns. The same result was obtained in the study of Ling and Naranjo (1997). However, evidence from the study of Mueller and Pauley (1995) suggests that REIT price movements are not explained by the movements in interest rates either in periods when interest rates are high or in periods of low interest rates. In the UK, Lizieri and Satchell (1997b) establish a significant non-linear relationship between the real rate of interest and property company stock prices.

Authors have considered further the predictive power of interest rates by including interest rate spreads in their models, in particular the spread between long- and short-term interest rates (Keim and Stambaugh, 1986; Mishkin, 1988; Fama and French, 1992). Interest rate spreads (also known as the term structure and yield curve) are usually measured as the difference in the returns between long-term Treasury bonds (of maturity, say, 10 or 20 years), and the one-month or three-month Treasury Bill rate. Estrella and Hardouvelis (1991) argue that the yield curve has extra predictive power beyond that contained in the short term interest rate, and can help predict GDP up to four years ahead. Research findings about the effects of this variable on the movements of real estate returns, however, are conflicting. Chan et al (1990) provided supporting evidence that the term structure affects real estate market returns, whereas Liu and Mei (1992) did not find any such evidence. Ling and Naranjo (1997) found that the spread variable could become important in particular periods.

Inflation rate influences are also considered important in the pricing of stocks. Ferson and Harvey (1991) argue that unanticipated inflation could be a source of economic risk and as a 
result a risk premium will also be added if the stock of firms has exposure to unanticipated inflation. The effects of the inflation rate are examined by using different estimates of inflation - that is the realised (actual) inflation rate, and unanticipated inflation. The latter is usually defined as the difference between the realised and the anticipated rate. The use of anticipated and unanticipated inflation as variables in econometric modelling requires some thought about how inflation expectations might be measured. Different approaches are followed by existing studies to estimate the expected inflation including Box-Jenkins autoregressive integrated moving average (ARIMA) procedures (see Chan et al, 1990), and the methodology suggested by Fama and Gibbons (1984) which is based on the difference between the Treasury Bill rate and the fitted expected real return (using an MA(1) procedure) (see also Ling and Naranjo, 1997). Chan et al (1990) found no evidence suggesting that anticipated inflation affects real estate returns. However, unexpected inflation was found to exert a consistent influence on real estate market returns. More recently, Ling and Naranjo (1997) did not demonstrate any significant influences from the estimated value of expected inflation, although some weak support was evident for the effect of the unanticipated part of inflation.

In several investigations, the use of the dividend yield curve to predict stock market returns is common (Fama and French, 1988; Campbell and Shiller, 1988; Ferson and Harvey, 1991; Kothari and Shanken, 1997). Liu and Mei (1997) used the dividend yield to explain equity REIT returns based on the assumption that movements in the dividend yield series are related to long-term business conditions and that they capture the same predictable components of returns as the interest rate spreads. Their results, however, did not indicate that the dividend yield is a significant parameter in a model explaining equity REIT returns. 
The remainder of the paper is organised in three sections. Section two outlines the methodology and discusses the prespecified variables which are assumed to convey information about the macroeconomy and influence property returns. Section three reports the results of the empirical examination. Section four concludes, links the results obtained from this study to the findings of existing research and identifies areas for further research.

\section{Methodology and Variable Descriptions}

The VAR approach that this paper utilises to examine the relationship between macroeconomic variables and real estate returns allows an interaction between all variables. The VAR model will take each of the variables in the system and relate its variation to its own past history and the past values of all the other variables in the system. A typical VAR model in standard form, with $p$ equations (one for each of $p$ variables) is described as:

$Y_{t}=\beta_{0}+\beta_{1} Y_{t-1}+\ldots+\beta_{m} Y_{t-m}+u_{t}$

where $\boldsymbol{Y}$ is the set (or $p \times 1$ vector) of variables included in the system, the $\boldsymbol{\beta}$ terms are the sets of coefficients $\left(\boldsymbol{\beta}_{\mathbf{0}}\right.$ is a $p \times 1$ vector of constants, $\boldsymbol{\beta}_{\mathbf{1}}, \ldots, \boldsymbol{\beta}_{\mathrm{m}}$ are $p \times p$ matrices of coefficients on the lagged variables, $m$ represents the number of lags of each variable in each equation, and $\boldsymbol{u}_{\boldsymbol{t}}$ is a set of error terms (or innovations) which are assumed to be mutually uncorrelated and independent of the $\boldsymbol{Y}_{\text {s. An }}$ unrestricted VAR system, by definition, does not impose any restrictions about which of the variables affect the others as would be the case in a regression model. Rather, it is simply assumed that variables are related to their own lagged values and the lagged values of the other variables over time. The VARs estimated in this paper are of a reduced form: that is, they use only lagged values of the variables on the right hand side and hence there is no simultaneity in the system. Theoretical insight is used to determine the 
variables to be included in the list $\boldsymbol{Y}$ and statistical tests are applied to determine the appropriate lag length $m$.

Following the discussion in the introduction above, the vector of variables $\boldsymbol{Y}$ in the VAR system proposed in this study comprises the following variables: property returns (PROP), rate of unemployment (UNEM), nominal short term interest rates (SIR), the interest rate spread (SPREAD), unanticipated inflation (UNINFL) and the dividend yield (DIVY). The source for all data series is Datastream International. The property returns series is the FTSE Property Total Return Index ${ }^{2}$. In the present study, the proposition by McCue and Kling (1994) that property returns are affected by overall stock market returns is taken into account before examining the effects of the macroeconomic variables on the real estate market. Following the procedure proposed and utilised by these authors, we regress property returns on the FTA All-Share Index, saving the residuals. These residuals, denoted PROPRES, are linearly independent of stock market effects (since they have now been purged of their contemporaneous general stock market influences), which can be investigated on the basis of the information contained in UNEM, SIR, SPREAD, UNINFL and DIVY. This step is known as orthogonalisation, and separates out that part of the real estate return which is linearly and contemporaneously related to movements in the general stock market. This is an important procedure, since the purpose of this paper is to model the real estate market itself rather than to pick up general market changes which affect the value of all stocks. Results in Brooks and Tsolacos (1998) demonstrate that this contemporaneous regression is sufficient to remove all significant stock market effects from the real estate return series.

\footnotetext{
2 The method of calculating the FTA property series used in a number of earlier studies was changed substantially in early 1994 so that the two vintages of data cannot be combined in a meaningful way. Hence the FTSE series was used instead so that the data used in the study was as recent as possible. The FTSE series used in this study only commenced in 1985 .
} 
The rate of unemployment refers to the number of workers who are unemployed but actively seeking work (in thousands). The nominal short term interest rate is the three month Treasury Bill rate. The interest rate spread is estimated as the difference between the three month Treasury Bill rate and the yield on twenty year UK gilts. The unanticipated inflation variable ${ }^{3}$ is defined as the difference between the realised inflation rate, computed as the percentage change in the Retail Price Index, and an estimated series of expected inflation. The latter series was produced by fitting an autoregressive integrated moving average (ARIMA) model to the actual series and making a one period (month) ahead forecast, then rolling the sample forward one period, and re-estimating the parameters and making another one-step ahead forecast and so on. The optimal lag lengths of the autoregressive and moving average parts were selected using Akaike's (1974) information criterion. Finally, the dividend yield is the dividend yield on the FTA All-Share Index. All data are transformed to their natural logarithms, and their frequency is monthly. As outlined above, the sample period is dictated by the availability of property returns data, and runs from December 1985 until January 1998, a total of 146 observations.

We require all variables included in the VAR to be stationary in order to carry out joint significance tests on the lags of the variables. Hence all the variables were subjected to augmented Dickey Fuller tests. We find strong evidence that the log of the retail price index and the $\log$ of the unemployment rate both contain a stochastic trend (that is, they are nonstationary). Therefore the first differences of these variables are used in subsequent analysis.

\footnotetext{
${ }^{3}$ We also estimated the VAR using actual inflation rather than unanticipated inflation, and the results were not markedly changed. Hence we present only results for the latter since this measure is more justifiable from a finance-theoretic perspective.
} 
All four other variables led to rejection of the null hypothesis of a unit root in the log-levels, and hence these variables were not first differenced.

For a VAR to be unrestricted, it is required that the same number of lags of all of the variables is used in all equations. Therefore, in order to determine the appropriate lag lengths, a multivariate generalisation of Akaike's (1974) information criterion (denoted AIC) is used. Within the framework of the VAR system of equations, the significance of all the lags of each of the individual variables is examined jointly with an $F$-test. Since several lags of the variables are included in each of the equations of the system, the coefficients on individual lags may not appear significant for all lags. However, F-tests will establish the joint significance of all of the lags of the individual variables.

In order to further consider the effect of the macroeconomy on the real estate returns index, we calculate the impact multipliers (orthogonalised impulse responses) for the estimated VAR model. Two standard error bands are also calculated using the Monte Carlo integration approach employed by McCue and Kling (1994), and based on Doan (1994). We also decompose the forecast error variance to determine the proportion of the movements in the real estate series that are a consequence of its own shocks rather than shocks to other variables. Then, if the $F$-test result for the lags of variable $\mathrm{X}$ in the equation for variable $\mathrm{Y}$ are not significant, we conclude that changes in variable $\mathrm{X}$ cannot cause subsequent changes in variable Y.

\section{Results}

Simple correlations for each of the variables used in subsequent analysis, both contemporaneously (zero lag) and at lag 12, are given in panel A and panel B of Table 1 
respectively. A couple of features are worthy of noting before progression to more complex analysis. First, for some combinations of variables, the pairwise correlations do not seem to damp down, even after one year. Second, there are very strong negative correlations between the short term interest rate and the term spread, and also between the term spread and the dividend yield. There is some negative correlation between the property returns, the term spread, and between property returns and the unemployment rate, although there is no correlation between the short term interest rate or the spread and property returns at the twelfth lag.

The first step in the empirical investigation is to examine how significant the information contained by the lagged values of the pre-specified variables chosen is in explaining the variation in property returns within the VAR framework. The number of lags to be included in the VAR is guided by the minimisation of the value of Akaike's information criterion. In this application, the selected number of lags is 14 , consistent with the 15 lags used by McCue and Kling (1994). F-tests for the null hypothesis that all of the lags of a given variable are jointly insignificant in a given equation are presented in Table 2 . In contrast to a number of US studies which have used similar variables, we find that it is difficult to explain the variation in the real estate returns index using macroeconomic factors, as the last row of Table 2 shows. Of all the lagged variables in the real estate equation, only the lags of the real estate index themselves are highly significant, and the dividend yield variable is only significant at the $20 \%$ level. No other variables have any significant explanatory power for the real estate return index. Therefore, based on the $F$-tests, an initial conclusion is that the variation in property returns, net of stock market influences, cannot be explained by any of the main macroeconomic or financial variables used in existing research. One possible explanation for this might be that in the UK, these variables do not convey the information 
about the macroeconomy and business conditions assumed to determine the inter-temporal behaviour of property returns. It is expected that property returns may reflect property market influences, such as rents, yield or capitalisation rates, rather than macroeconomic or financial variables. However, again the use of monthly data limits the set of both macroeconomic and property market variables that can be used in the quantitative analysis of real estate returns in the UK.

It appears, however, that lagged values of the real estate variable have explanatory power for some other variables in the system. These results are shown in the last column of Table 2 . The property sector appears to help to explain variations in the term structure and short term interest rates, and moreover since these variables are not significant in the property index equation, it is possible to state further that the property residual series Granger-causes the short term interest rate and the term spread. The fact that property returns are explained by own lagged values, that is there is interdependency between neighbouring data points (observations), may reflect the way that property market information is produced and reflected in the property return indices. The implication is that new information is only slowly reflected in quoted property company prices, net of general stock market influences, property returns may have predictive power for future property returns.

Further information about the relationships between the pre-specified variables and property returns is generated by the variance decompositions and impulse responses. Variance decompositions seek to determine what proportion of the changes in the real estate return series can be attributed to changes in the lagged explanatory variables. Impulse responses, (also known as impact multipliers) seek to determine what the effect a one-unit shock of each explanatory variable will have upon the real estate return series over time. Table two gives 
variance decompositions for the property returns index equation of the VAR for $1,2,3,4,12$ and 24 steps ahead for the two variable orderings

Order I: $\quad$ PROPRES, DIVY, UNINFL, UNEM, SPREAD, SIR

Order II: $\quad$ SIR, SPREAD, UNEM, UNINFL, DIVY, PROPRES

Unfortunately, the ordering of the variables is important in the decomposition since it is effectively equivalent to an identifying restriction on the primitive form of the VAR. Thus we follow Mills and Mills (1991) in applying two orderings, which are the exact opposite of one another, and considering the sensitivity of the results. It is clear that by the two year forecasting horizon, the variable ordering has become almost irrelevant in most cases. An interesting feature of the results is that shocks to the term spread and unexpected inflation together account for over $50 \%$ of the variation in the real estate series. The short term interest rate and dividend yield shocks account for only $10-15 \%$ of the variance of the property index. One possible explanation for the difference in results between the $F$-tests and the variance decomposition is that the former is a causality test and the latter is effectively an exogeneity test. Hence the latter implies the stronger restriction that both current and lagged shocks to the explanatory variables do not influence the current value of the dependent variable of the property equation. Another way of stating this is that the term structure and unexpected inflation have a contemporaneous rather than lagged effect on the property index, which implies insignificant $F$-test statistics but explanatory power in the variance decomposition. Therefore, although the $F$-tests did not establish any significant effects, the error variance decompositions show evidence of a contemporaneous relationship between PROPRES and both SPREAD and UNINFL. The lack of lagged effects could be taken to imply speedy adjustment of the market to changes in these variables. 
Figures 1 to 6 give the impulse responses associated with unit shocks in each of the six explanatory variables. Considering the signs of the responses, unexpected inflation always has a negative impact on the real estate index, since the impulse response is negative, and the effect of the shock does not die down, even after 24 months. Increasing stock dividend yields have a negative impact for the first three periods, but beyond that, the shock appears to have worked its way out of the system. An increase in the differential between the yield on long and short term bond yields also has a negative, but slowly strengthening impact on the real estate market as the shock works through. An increase in the differential might be indicative that the markets expect the spot interest rate to rise in the future, and hence its effect will only be felt in the real estate series with a lag. The short term interest rate itself has a negative impact on real estate for 6 months following an increase (a finding which corroborates the results of McCue and Kling), by which time the effect is reversed, although the relationship is never very strong. It is also worth stating that the standard error bands for the impulse responses are rather wide and also diverge from the actual responses as the horizon increases, and in particular, apart from dividend yield up to 3 steps ahead, the term spread, and the property index itself up to 12 steps ahead, the two standard error bands span both sides of the zero axis thus making the impulse responses otherwise insignificant in a statistical sense.

\section{Conclusions}

Research on the predictability of real estate returns, an area of significant interest to property analysts and investors, requires that the linkages between real estate returns and the macroeconomic and financial environment are empirically established. Following the insight of studies on stock market returns, it is expected that a relationship should exist between certain macroeconomic financial variables and returns on property backed assets. This paper is motivated by the lack of such research in the UK context and provides a study of property 
returns, proxied by the FTSE Property Total Return Index, and key economic and financial variables which have been used in quantitative work with US data. This return series is filtered to extract general stock market influences on its movements. This allows a more factual investigation of the impact of the prespecified variables - nominal short-term interest rates, dividend yields, the interest rate spread, the rate of unemployment and unanticipated inflation - on property returns.

The conclusion from the VAR methodology adopted in this paper is that the overall, UK real estate returns purged of general stock market influences are difficult to explain on the basis of the information contained in the set of the variables used in existing studies based on non-UK data. The results are not strongly suggestive of any significant influences of these variables on the variation of the filtered property returns series. There is however some evidence that the interest rate term structure and unexpected inflation have a contemporaneous effect on property returns, in agreement with the results of a number of previous studies. Given that the existing literature has provided conflicting support to the effects originating in the variables used in the present study, it can be stated that these results are not at variance with established facts. Since these apparently conflicting results are typically based on different methodologies and different returns series, it is inferred that the estimation output of existing studies is sensitive to the particular measure or series of property returns used, the sample period and the type of model employed. This issue needs to be investigated with further comparative work across international markets. Finally, the present study has not exhausted the effect of direct, real macroeconomic variables on property returns in the UK due to lack of data at the monthly frequency. Further work can estimate models on quarterly data, using different econometric techniques. A further area of research would be to examine whether the 
predictability of returns in the UK presents investors with the opportunity of achieving excess trading profits.

\section{References}

Akaike, H. (1974) A new look at the statistical model identification, IEEE Transactions on Automatic Control AC-19(6), 716-23.

Breeden, D. (1979) An intertemporal asset pricing model with stochastic consumption and investment opportunities, Journal of Financial Economics 7, 256-96.

Breeden, D., Gibbons, M. and Litzenberger, R. (1989) Empirical tests of the consumptionorientated CAPM, Journal of Finance 44, 231-62.

Brooks, C. and Tsolacos, S. (1998) Does Orthogonalisation Really Purge Equity-Based Property Valuations of their General Stock Market Influences?, forthcoming in Applied Economics Letters

Campbell, J. (1987) Stock returns and the term structure, Journal of Financial Economics 18, 373-99.

Campbell, J. and Shiller, R. (1988) The dividend price ratio and expectations of future dividends and discount factors, Review of Financial Studies 1, 195-228.

Chan, K.C., Hendershott, P.H. and Sanders, A.B. (1990) Risk and return on real estate: evidence from equity REITs, American Real Estate and Urban Economics Association Journal 18, 431-52.

Chen, N-F. (1991) Financial investment opportunities and the macroeconomy, Journal of Finance 46, 529-554.

Chen, N., Roll, R. and Ross, S. (1986) Economic forces and the stock market, Journal of Business 59, 383-403.

Doan, T. (1994) Regression Analysis of Time Series User Manual, 4th ed., Estima.

Estrella, A. and Hardouvellis, G. (1991) The term structure as a predictor of real economic activity, Journal of Finance 46(2), 555-76.

Fama, E.F. and French, K.R. (1993) Common risk factors in the returns on stocks and bonds, Journal of Financial Economics 33, 3-56.

Fama, E.F. and French, K.R. (1992) The cross-section of expected stock returns, Journal of Finance 47, 427-65. 
Fama, E.F. and French, K.R. (1989) Business conditions and expected returns on stocks and bonds, Journal of Financial Economics 25, 23-49.

Fama, E.F. and Gibbons, M. (1984) A comparison of inflation forecasts, Journal of Monetary Economics 13, 327-48.

Ferson, W. and Harvey, C. (1991) The variation of economic risk premiums, Journal of Political Economy 99, 385-415.

Keim, D.B. and Stambaugh, R.F. (1986) Predicting returns in the stock and bond markets, Journal of Financial Economics 17, 357-90.

Kothari, S.P. and Shanken, J. (1997) Book-to-market, dividend yield, and expected market returns: a time-series analysis, Journal of Financial Economics 44, 169-203.

Lawrence, C. and Siow, A. (1985) Interest rates and investment spending: some empirical evidence for postwar U.S. producer equipment, 1947 - 1980: Journal of Business 58(4), 359-75.

Ling, D. and Naranjo, A. (1997) Economic risk factors and commercial real estate returns, Journal of Real Estate Finance and Economics 14(3), 283-307.

Lizieri, C. and Satchell, S. (1997a) Property company performance and real interest rates: a regime switching approach, Journal of Property Research 14, 85-97.

Lizieri, C. and Satchell, S. (1997b) Interactions between property and equity markets: an investigation of linkages in the UK 1972-1992, Journal of Real Estate Finance and Economics 15(1), 11-26.

Liu, C.H. and Mei, J. (1992) The predictability of returns on equity REITs and their comovement with other assets, Journal of Real Estate Finance and Economics 5, 40118.

Lucas, R.E.,Jr (1978) Asset prices in an exchange economy, Econometrica 46, 1429-45.

McCue, T.E. and Kling, J.L. (1994) Real estate returns and the macroeconomy: some empirical evidence from real estate investment trust data, 1972-1991, Journal of Real Estate Research 9(3), 277-87.

Mills, T.C. and Mills, A.G. (1991) The international transmission of bond market movements, Bulletin of Economic Research 43(3), 273-81.

Mishkin, F.S. (1988) The information in the term structure: some further results, Journal of Applied Econometrics 3, 307-14.

Mueller, G. and Pauley, K. (1995) The effect of interest-rate movements on real estate investment trusts, Journal of Real Estate Research 10(5), 319-25. 
Mueller, G. and Ziering, B.A (1992) Real estate portfolio diversification using economic diversification, Journal of Real Estate Research 7(4), 375-86.

Peterson, J.D. and Hsieh, C-H. (1997) Do common risk factors in the returns on stocks and bonds explain returns on REITs? Real Estate Economics 25(2), 321-45.

Royal Institution of Chartered Surveyors (1994), Economic Cycles and Property Cycles: Final Report, London: Royal Institution of Chartered Surveyors. 
Table 1: Simple Cross-Correlations for Variables: Contemporaneous and at Lag 12

\begin{tabular}{ccccccc}
\hline & \multicolumn{6}{c}{ Panel A: Contemporaneous Correlations } \\
& SIR & DIVY & SPREAD & UNEM & UNINFL & PROPRES \\
\hline SIR & - & 0.562 & -0.942 & 0.172 & 0.027 & 0.288 \\
DIVY & - & - & -0.400 & 0.317 & 0.000 & -0.284 \\
SPREAD & - & - & - & -0.131 & -0.012 & -0.410 \\
UNEM & - & - & - & - & -0.309 & -0.276 \\
UNINFL & - & - & - & - & - & 0.082 \\
PROPRES & - & - & - & - & - & - \\
\hline & & & Panel B: Correlation at lag 12 & & \\
& SIR & DIVY & SPREAD & UNEM & UNINFL & PROPRES \\
\hline SIR & - & 0.624 & -0.590 & 0.172 & -0.062 & 0.003 \\
DIVY & - & - & -0.620 & 0.052 & 0.026 & -0.345 \\
SPREAD & - & - & - & -0.343 & 0.047 & -0.015 \\
UNEM & - & - & - & - & -0.245 & -0.342 \\
UNINFL & - & - & - & - & - & 0.079 \\
PROPRES & - & - & - & - & - & - \\
\hline
\end{tabular}


Table 2: Marginal Significance Levels associated with Joint $F$-tests that all 14 Lags have no Explanatory Power for that particular Equation in the VAR

Lags of Variable

\begin{tabular}{|c|c|c|c|c|c|c|}
\hline Dependent variable & SIR & DIVY & SPREAD & UNEM & UNINFL & PROPRES \\
\hline SIR & 0.0000 & 0.0091 & 0.0242 & 0.0327 & 0.2126 & 0.0000 \\
\hline DIVY & 0.5025 & 0.0000 & 0.6212 & 0.4217 & 0.5654 & 0.4033 \\
\hline SPREAD & 0.2779 & 0.1328 & 0.0000 & 0.4372 & 0.6563 & 0.0007 \\
\hline UNEM & 0.3410 & 0.3026 & 0.1151 & 0.0000 & 0.0758 & 0.2765 \\
\hline UNINFL & 0.3057 & 0.5146 & 0.3420 & 0.4793 & 0.0004 & 0.3885 \\
\hline PROPRES & 0.5537 & 0.1614 & 0.5537 & 0.8922 & 0.7222 & 0.0000 \\
\hline
\end{tabular}

Table 3: Variance Decompositions for the Property Sector Index Residuals

Explained by innovations in

\begin{tabular}{|c|c|c|c|c|c|c|c|c|c|c|c|c|}
\hline \multirow[b]{2}{*}{ Months ahead } & \multicolumn{2}{|c|}{$\underline{\text { SIR }}$} & \multicolumn{2}{|c|}{$\underline{\text { DIVY }}$} & \multicolumn{2}{|c|}{ SPREAD } & \multicolumn{2}{|c|}{ UNEM } & \multicolumn{2}{|c|}{$\underline{\text { UNINFL }}$} & \multicolumn{2}{|c|}{$\underline{\text { PROPRES }}$} \\
\hline & $\mathrm{I}$ & II & I & II & $\mathrm{I}$ & II & I & II & I & II & I & II \\
\hline 1 & 0.0 & 0.8 & 0.0 & 38.2 & 0.0 & 9.1 & 0.0 & 0.7 & 0.0 & 0.2 & 100.0 & 51.0 \\
\hline 2 & 0.2 & 0.8 & 0.2 & 35.1 & 0.2 & 12.3 & 0.4 & 1.4 & 1.6 & 2.9 & 97.5 & 47.5 \\
\hline 3 & 3.8 & 2.5 & 0.4 & 29.4 & 0.2 & 17.8 & 1.0 & 1.5 & 2.3 & 3.0 & 92.3 & 45.8 \\
\hline 4 & 3.7 & 2.1 & 5.3 & 22.3 & 1.4 & 18.5 & 1.6 & 1.1 & 4.8 & 4.4 & 83.3 & 51.5 \\
\hline 12 & 2.8 & 3.1 & 15.5 & 8.7 & 15.3 & 19.5 & 3.3 & 5.1 & 17.0 & 13.5 & 46.1 & 50.0 \\
\hline 24 & 8.2 & 6.3 & 6.8 & 3.9 & 38.0 & 36.2 & 5.5 & 14.7 & 18.1 & 16.9 & 23.4 & 22.0 \\
\hline
\end{tabular}


Figure 1: Impulse-Responses and Standard Error Bands for Innovations in Unexpected Inflation

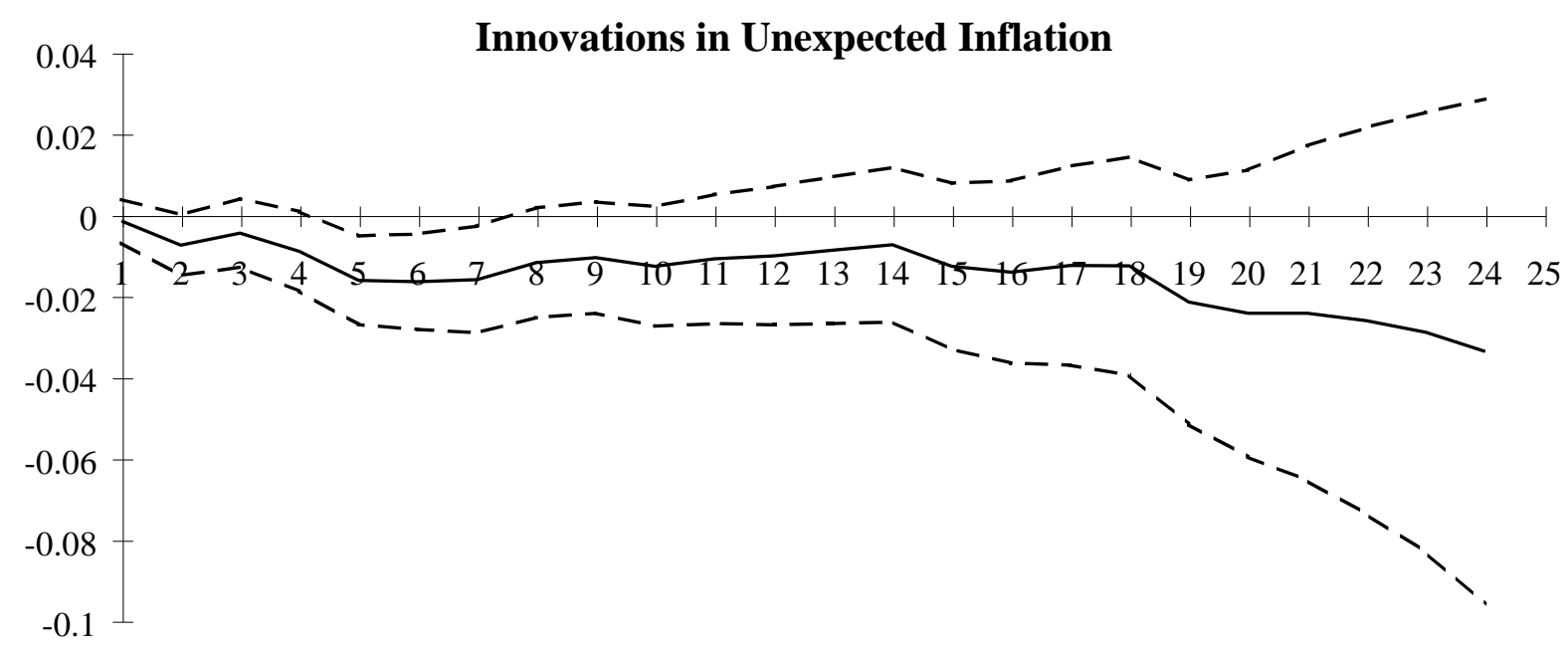

Steps Ahead 
Figures 2 \& 3: Impulse-Responses and Standard Error Bands for Innovations in Dividend Yields and the Term Spread

\section{Innovations in Dividend Yields}

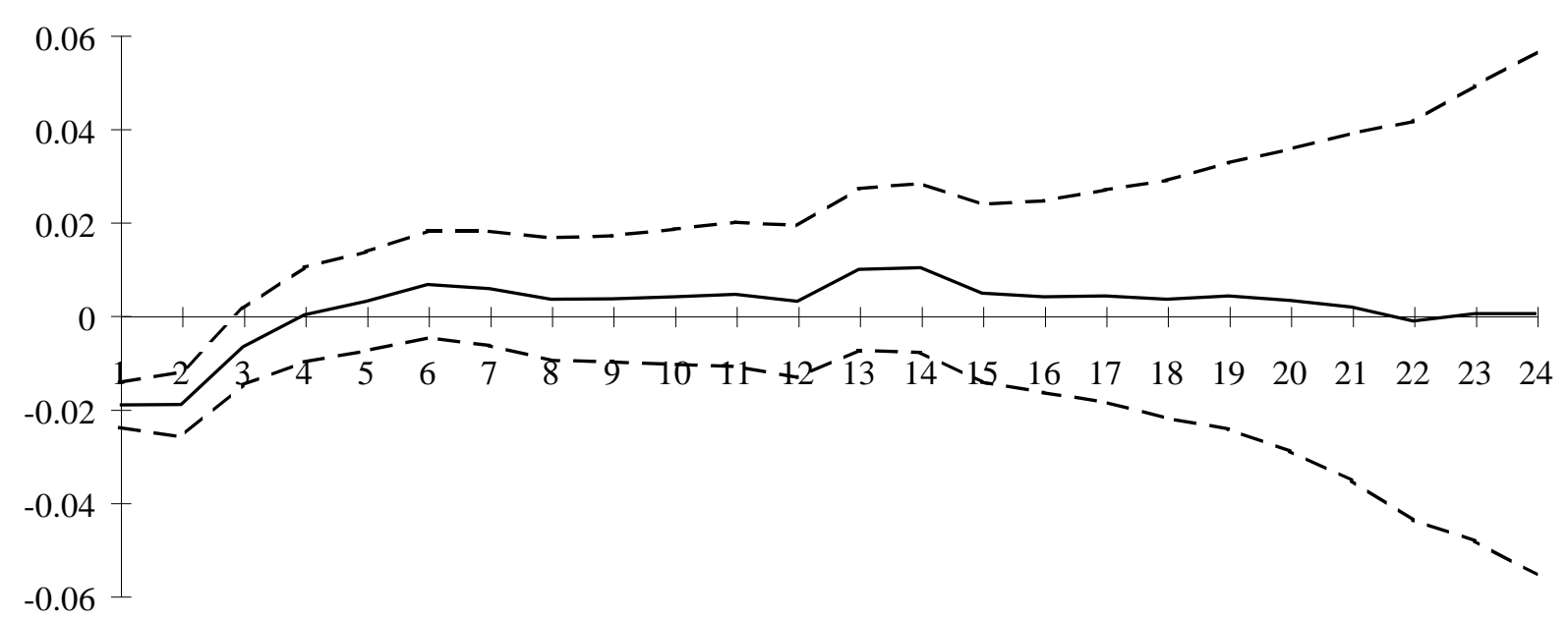

Steps Ahead

\section{Innovations in the Term Spread}

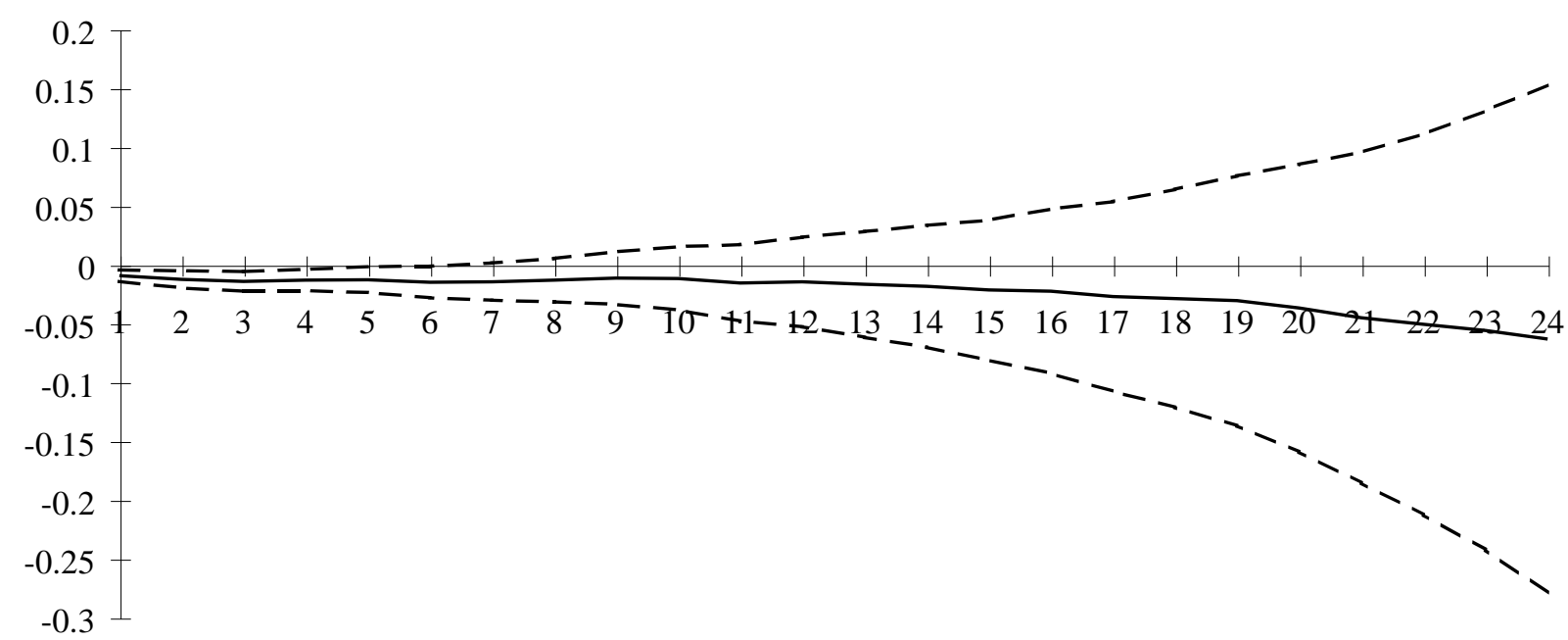

Steps Ahead 
Figures 4 \& 5: Impulse-Responses and Standard Error Bands for Innovations in the TBill Yield and the Property Index

\section{Innovations in the T-Bill Yield}

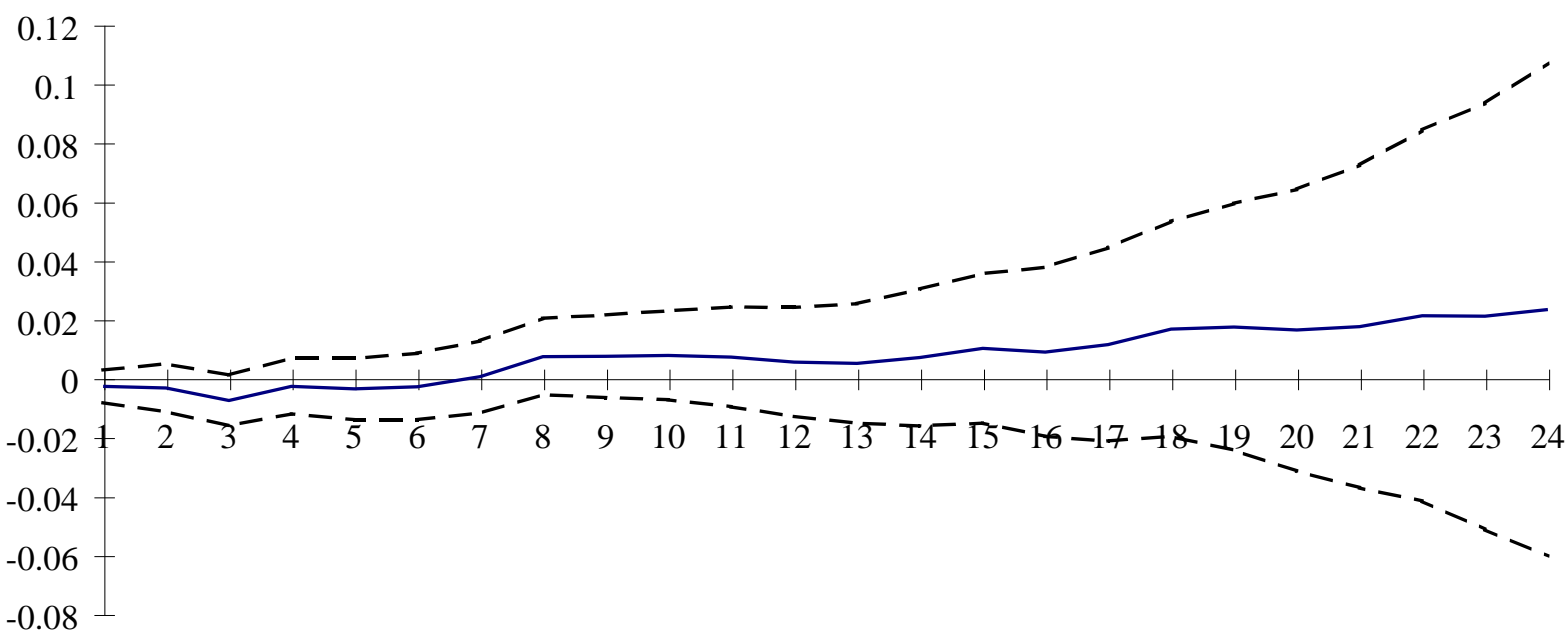

Steps Ahead

Innovations in the Property Index

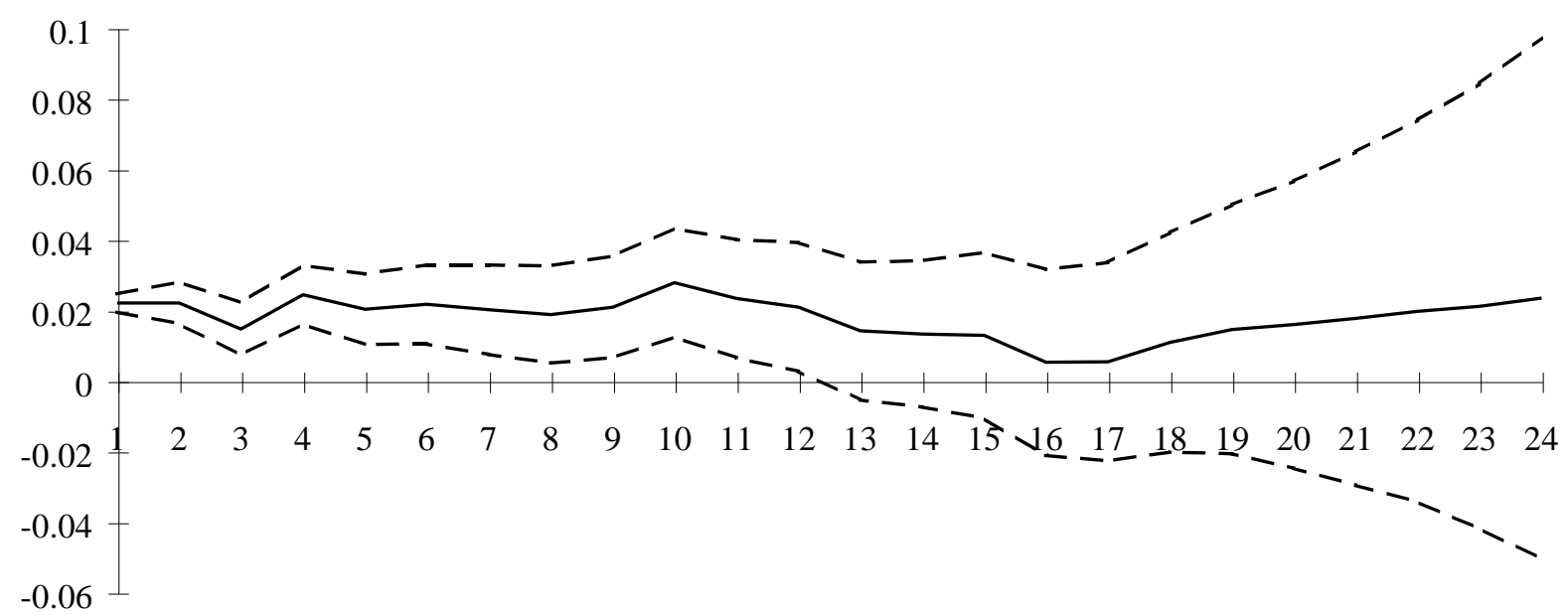

Steps Ahead 
Figure 6: Impulse-Responses and Standard Error Bands for Innovations in the

\section{Unemployment Rate}

Innovations in the Unemployment Rate

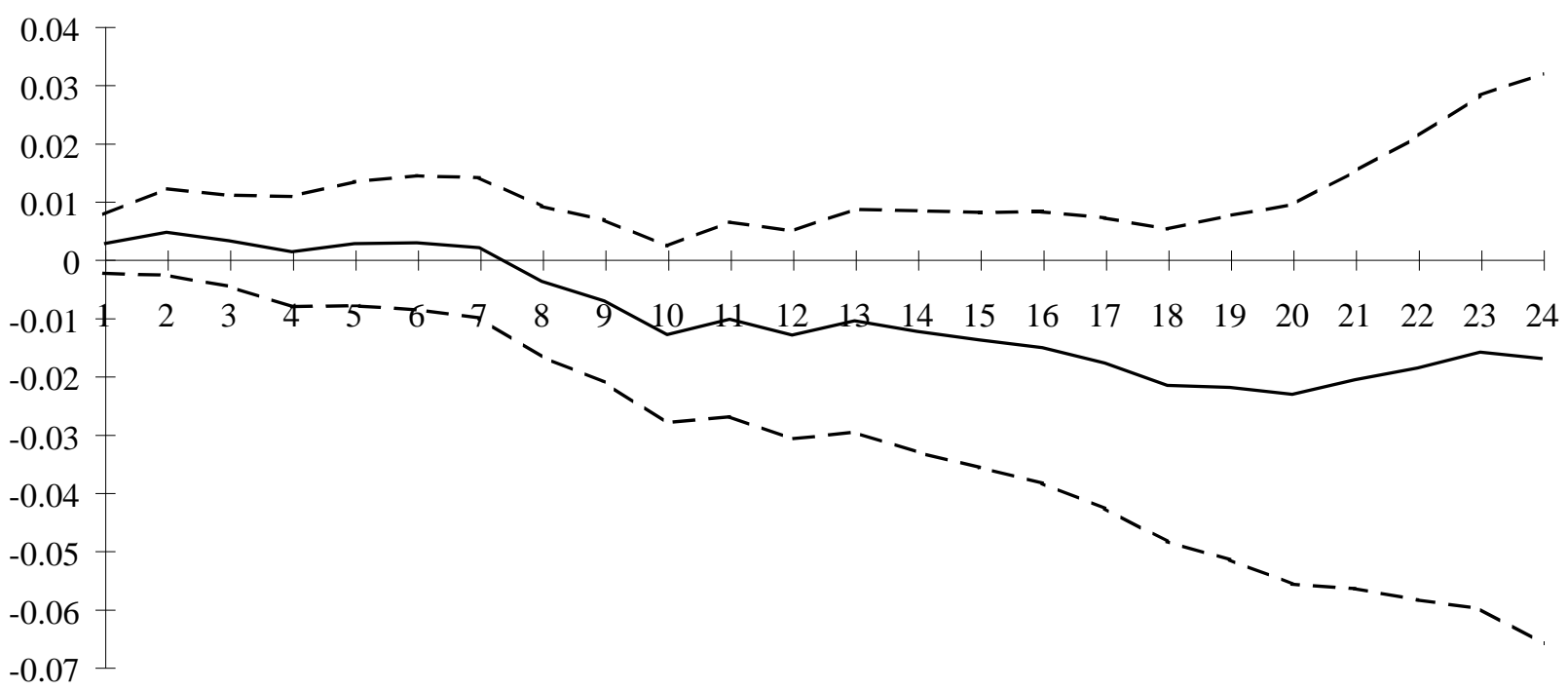

Steps Ahead 